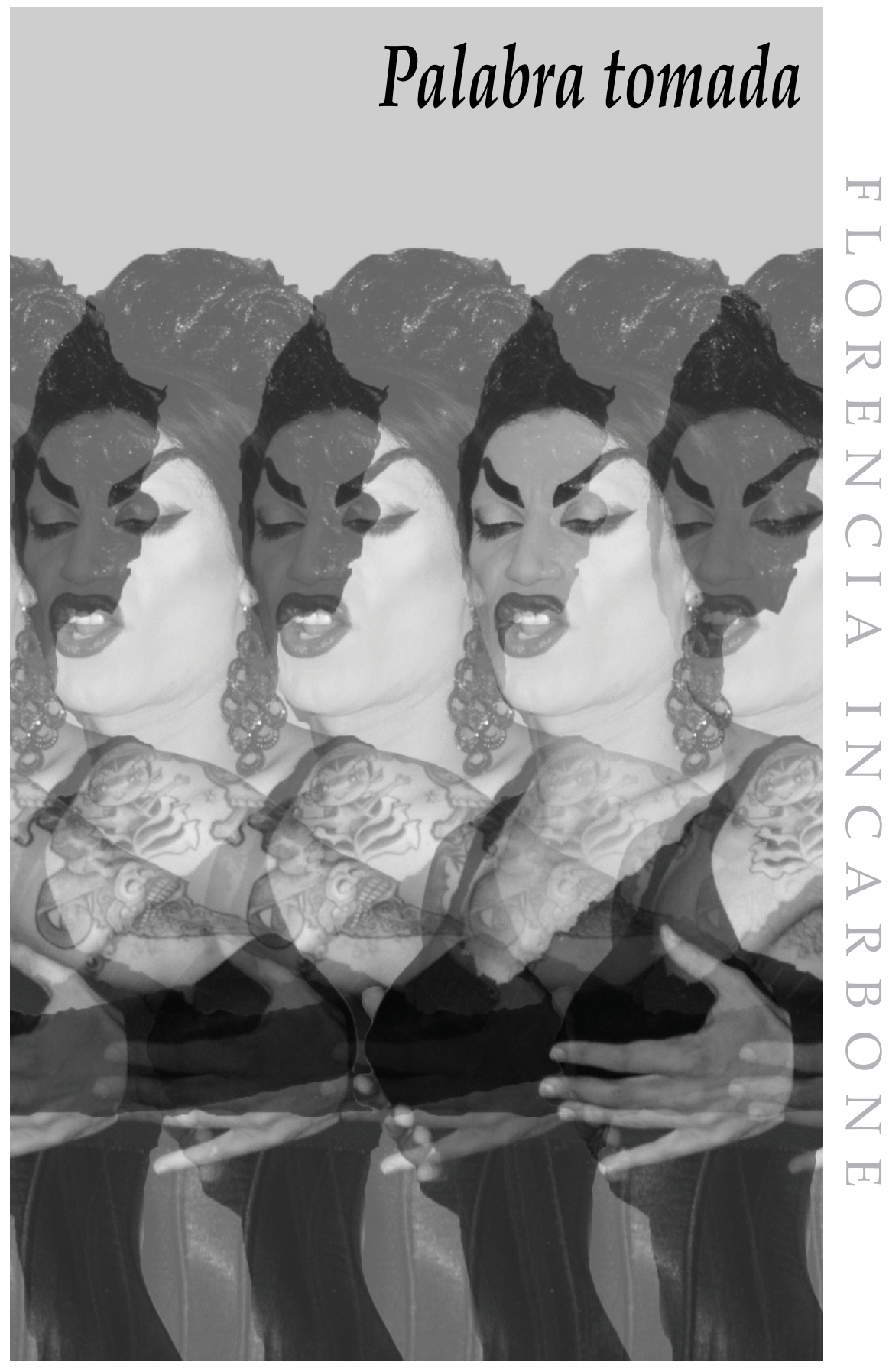





\section{Asediar la literatura, la política y la cultura: conversación con la escritora chilena Eugenia Prado Bassi}

Krzysztof Kulawik

Esta conversación tuvo lugar en el departamento de la escritora en Ñuñoa, Santiago de Chile, el 21 de marzo, 2009. Eugenia Prado Bassi es novelista y dramaturga, ha incursionado en las artes visuales y es editora de un sello propio, Ceibo Ediciones, junto al escritor y guionista Dauno Tótoro. En 1987, se tituló como diseñadora gráfica en la Pontificia Universidad Católica de Chile en Santiago y publicó su primera obra, la novela experimental El cofre. Siguieron Cierta femenina oscuridad -una novela dramatúrgica en 1996, la novela Lóbulo en 1998, luego una reedición de El cofre en 2000, Hembros: Asedios a lo post-humano -novela instalación estrenada en 2004, Desórdenes mentales -obra dramática estrenada en 2005, y Objetos del silencio en 2007 -relatos en forma novelada. En 2011, publicó la novela visual (con su propia gráfica) Dices miedo con Ceibo Ediciones. Prado ha recibido apoyos del Consejo de la Cultura y las Artes en varias ocasiones para auspiciar la creación de algunas de sus obras, particularmente para la escenificación de la novela-instalación Hembros, que culminó con la publicación de un disco compacto, con música de John Streeter y video del montaje.

En Chile, Ricardo Loebell se interesó por la obra de Prado desde El Cofre, uno de los pocos libros publicados por una mujer joven en tiempos de la dictadura militar, y su interés aumentó con la novela Lóbulo. En 2000, Loebell escribió el artículo "Repeso de un ensayo: a propósito de la narrativa de Eugenia Prado". También, en 
1998 aparece "No way out: Comentario a Lóbulo de Eugenia Prado" escrito por Martín Hopenhayn -filósofo, escritor e investigador chileno. A su vez, José Salomón actualmente hace investigación de doctorado en Literatura en la Universidad de Chile, en la que Prado aparece junto a Juan Pablo Sutherland y a Cinthya Rimsky como sujetos femenino, homosexual y migrante que construyen lugares marginales como estrategias y prácticas de escrituras.

En el caso de Prado, estamos frente a una escritura marginal que bordea otras aristas dentro del espectro narrativo en Chile. Su obra literaria ha detonado interés en EE.UU. Un artículo que se destaca por su análisis del tema de la relación entre lo humano y la tecnología es "Identidad poshumana en Lóbulo de Eugenia Prado" de Andrew Brown, publicado en Revista Iberoamericana. Explora cómo una novela, que marcadamente no es de ciencia-ficción, depende de imágenes y expresiones de la identidad posthumana para estetizar nuevas mentalidades. Incorpora críticamente las teorías posthumanas y cyborguianas de Donna Haraway y Katherine Hayles, y las de Gilles Deleuze y Félix Guattari, para analizar la articulación de cuerpos y subjetividades cuya naturaleza orgánica es alterada de manera fundamental por la tecnología ubicua que los rodea. En Lóbulo, específicamente, Brown señaló propuestas de una visión estética de la identidad posthumana que van más allá de las teorías cyborguianas basadas en la literatura norteamericana y europea.

Esa mañana soleada de marzo santiaguino, la conversación con Eugenia tomó varios rumbos, desde un recorrido cronológico de sus obras, pasando por temas de la cultura, la política, el trabajo del escritor y del académico, el contexto literario en Chile hasta abordar las identidades fragmentadas y transformadas (la desintegración del "yo" estable) en un contexto mediatizado por las nuevas tecnologías de comunicación y el correspondiente trabajo "en filigrana" que hace la escritora al interior del lenguaje -la palabra barroca- como medio de expresión de este nuevo ser mutado.

\section{LOS COMIENZOS}

Krzysztof Kulawik (en adelante KK): No es solo textual tu trabajo. No es que seas una novelista o escritora como tradicionalmente se 
percibe.

Eugenia Prado (en adelante EP): En el número 221 de la Revista Iberoamericana (octubre-diciembre de 2007) se publicó un artículo de Andrew Brown sobre mi novela Lóbulo, que fue estudiada en un doctorado en la Universidad Washington en St. Louis. En nuestros intercambios vía email, Andrew me decía que le parecía extraño que en un país como Chile una mujer planteara temas de tecnologías y máquinas. Mi trabajo se inició en espacios relacionados más con las artes visuales que con la literatura. Confieso además, que tenía miedo de leer textos teóricos con un rigor académico que definitivamente no tengo.

KK: Tal vez la academia presenta otra perspectiva sobre el mismo asunto que es la creación. Me parece que tú transitas entre varios espacios literarios, artísticos y filosóficos.

EP: La escritura es una de mis principales motivaciones en esta vida. De hecho, estoy escribiendo otra novela ahora. Y publiqué hace poco. KK: ¿Y esta última obra no es Hembros?

EP: Es Hembros ${ }^{1}$, novela en proceso cuyo primer manuscrito pude terminar luego de ganar un fondo del Consejo del Libro, y que culminó con el estreno de Hembros en 2004. En paralelo, empecé a trabajar en la novela Objetos del silencio, mi última publicación en 2007. Hoy, vuelvo a Hembros porque siento que en este texto hay gran cantidad de materiales y escrituras acumuladas. Lo que me interesa trabajar es el texto, textos como bloques sólidos, como discursos en confrontación, combinar voces múltiples y ampliar posibilidades. Vivimos los tiempos de la revolución tecnológica, de las comunicaciones. Y por lo mismo, me interesa trabajar este libro como testimonio de este cambio poderoso desde la experiencia personal. Es para dar cuenta de este proceso, tal vez más potente que en la Edad Media y el Renacimiento; además, tenemos el privilegio de ser los actores...

KK: Hablemos de las tres novelas: El cofre, Lóbulo y Objetos del silencio. Han pasado más de veinte años desde que salió la primera. ¿Qué motivó tu actividad artística inicialmente?

EP: Tenía veinticuatro años cuando publiqué mi primer libro. Salí muy joven del liceo, con diecisiete años recién cumplidos entré a la escuela de diseño de la Universidad Católica para estudiar una carrera que se estaba abriendo en nuestro mercado y que no se sabía 
en qué dirección iba. Hablo de inicios de los 80, años previos al plebiscito para derrocar al dictador Augusto Pinochet en 1988. Aún en dictadura se publica mi primer libro. Bastante joven y sin vínculos directos con gente que participara en los movimientos políticos, entré a estudiar al Campus El Comendador, un lugar más bien de clases altas, de gente que en gran mayoría no estaba comprometida con estos temas y casi no se hablaba de dictadura. Desde mis rebeldías empecé a escribir en paralelo a mis estudios de diseño.

KK: ¿Cómo te hallabas en ese ambiente?

EP: Me sentía bastante desfasada en ese lugar, tenía muy poco que ver conmigo pero me estaba dando buenas herramientas en lo creativo. En paralelo, tuve la suerte de conocer a Eugenia Brito, poeta chilena excepcional, que trabaja y construye, en mi opinión, un sujeto femenino latinoamericano "otro", que se articula como lengua en la palabra y la letra, y que además de poeta es una teórica brillante. Una amiga común nos presentó, me acerqué a ella para pedirle que leyera mi libro, compartimos la lectura del primer manuscrito. Esa noche estábamos en su departamento y de pronto se apagó la luz (en plena dictadura era común vivir estos apagones). Encendió algunas velas y empezamos a leer El cofre. Fue una noche inolvidable porque la atmósfera era completamente inusual. Eugenia leía cosas y decía: "esto es maravilloso". Luego, decía: "eso no, tienes que sacarlo, por favor sácalo", con mucha propiedad sobre el texto. Desde ese momento nos hicimos muy amigas, sentí su apoyo, complicidad y compromiso con mi escritura. Luego me presentó a Diamela Eltit, que también leyó El cofre y que tiempo después me invitó a participar en la organización previa del Congreso Internacional de Literatura Femenina Latinoamericana en Chile en agosto de 1987. Allí, tuve el privilegio de compartir con las escritoras y pensadoras más potentes de esos años, mujeres como Nelly Richard, Diamela Eltit, Eugenia Brito, Carmen Berenguer entre otras. Entonces, con apoyo de Leonardo Ahumada, amigo de esos años, hicimos El cofre, una autoedición -en esos tiempos no había computadoras-con muy pocas herramientas de diseño, fue muy precario. En la contraportada, aparece el texto de presentación de Diamela Eltit, hasta con su firma que era todo un lujo. Si quieres, leemos un pedacito: "Diez años un hombre mayor habita en igualdad a todo recuerdo, oprime al cráneo en la aspereza de sus manos llenas de carne y voluptuosidad. Su piel 
nunca fría, despierta al candor adolescente de sus primeros intentos, sus manos más aún que el candor que sugieren, son muchas veces dolorosas, se le presentan inquisidoras al golpe. Place al dolor la piel en rebeldía, oprime al rubor en tanto blasfema" (Prado 1987, 7). Te fijas que hay una construcción poética y extraña, es lo que buscaba. KK: Es altamente sensual y poético, es casi como escuchar poesía pero escrita en prosa, con un lenguaje rico en impresiones sensoriales. EP: A Diamela Eltit y a Eugenia Brito les interesó mi proyecto de escritura, el contexto en que se había creado y que yo fuera una mujer joven, lo que fue un importante punto de partida. Este libro tenía que ver con todos estos lugares intelectuales que frecuentaba donde se trabajaban textos teóricos y discursos políticos, en amplios sentidos. Publicar con veinticuatro años en ese contexto histórico fue un gesto político.

KK: Ya veo por el tipo de discurso poético que esto no es una narración lineal, sino interiorizada, un fluir de consciencia casi sin trama.

EP: Esta historia tiene que ver con el lugar de la resistencia que se daba en una generación de jóvenes, de entre diecisiete y veinticinco años, que vivíamos con miedo y a la vez con rebeldía, y en esa fragilidad nos acompañábamos. Entonces, busqué descomponer los textos y usar un lenguaje críptico para establecer códigos menos explícitos de todo lo que estaba sucediendo. Entre los jóvenes de esa época algunos habían vivido la dictadura muy de cerca. Nos juntábamos en fiestas clandestinas en Matucana 19, con la auténtica necesidad de construir espacios comunes y de resistencia.

KK: Comenzaste a escribir en una época de cambios radicales, y la narrativa que escribías en esa época refleja bastante ese lugar de resistencia. En ese tiempo, tal vez un poco antes, apareció la novela Lumpérica de Diamela Eltit, una obra bien experimental. Si tratáramos de ubicar tu obra en el contexto chileno contemporáneo, ¿podríamos decir que ofreces, junto con la narrativa de Eltit, una alternativa al canon neorrealista del postboom, desde los años 80 hasta tus obras posteriores?

EP: Diamela Eltit es una escritora brillante, su libro Lumpérica fue publicado por Ediciones del Ornitorrinco en 1983, ella es y será referente fundamental para muchos, escritoras y escritores, no solo en Chile, y es perfecto que así sea; compartíamos un momento 
histórico, en un país devastado.

KK: Con una voz distinta y cruces de géneros, no solo literarios sino de artes visuales.

EP: En el año 2000, casi catorce años después, publiqué una reedición de El cofre (Surada Ediciones), con full-diseño y todo. Allí pude ejercer mi oficio con propiedad, trabajar con la gráfica y hacer lo que quisiera, a diferencia de la escuela de diseño donde imponían lo que no podía hacerse. Siento que me estaba anticipando en la gráfica y fui una auténtica rebelde durante los años de estudiante y con ese libro me sentí libre de un pasado asfixiante...

KK: Jugando con los textos, las caligrafías y el aspecto visual.

EP: En el título de la portada del "primer Cofre" jugué con alteraciones de tipografías y tamaños, en el diseño del "segundo Cofre" tuve además el apoyo de Eugenio Dittborn, destacado artista chileno. Además, incluí un prólogo de Juan Pablo Sutherland de alto vuelo, "La extraña tonalidad del lenguaje tránsfuga de Eugenia Prado". Tiene estas partes, las voy a nombrar. Uno: "La densidad del lenguaje", dos: "El habla como rito", tres: "La disolución de los géneros", cuatro: "La impostura de la voz como recurso" (fíjate en estos títulos que es lo más lindo), cinco: "El cuerpo como carencia", seis: "La fragmentariedad versus la totalidad", siete: "La grafía como huella, el diseño como señuelo", ocho: "La disidencia como señalética de una zona", nueve: "La fragilidad perversa versus el sujeto histórico de los ochenta: los indicios y rastros de una escritora tránsfuga". Está todo ahí, creo que ese prólogo es de lo más potente que se ha escrito sobre mi obra, junto con lo que escribió Diego Ramírez para la presentación de Objetos del silencio, porque son textos de una sensibilidad que no solo pasa por lo estético o lo teórico, sino también por los afectos.

\section{LOS AÑOS 90}

EP: Luego de la experiencia del Congreso de Literatura Femenina Latinoamericana del 87, decidí concentrarme en el proyecto de la nueva novela Lóbulo y me encerré a trabajar, lejos de los circuitos literarios seguí trabajando en diseño y en mis escrituras hasta el año 1995. Trabajaba en dos libros: Cierta femenina oscuridad y Lóbulo. Esta última fue la primera novela después de El cofre, pero se publicó 
dos años después del segundo libro (Cierta...), en 1998. Lóbulo me tomó nueve años de trabajo; su personaje, Sofía, creció conmigo. Es la historia de una mujer que recibe persistentes llamadas telefónicas de una voz desconocida, metálica y maquinal. La voz detona cosas extrañas en ella y que van alterando su percepción del mundo exterior. Producto de ese pacto máquina/carne, auricular/ oído, se engendra un hijo. Es la propia escritura que pulsa por salir. El teléfono-máquina-aparato-prótesis captura sus órganos para engendrar un feto que viene con un único propósito: destruir a su madre. Coincidió que en el tiempo de gestación y de producción vivía con un psiquiatra, así que también trabajé e investigué bastante el tema de la enfermedad, lo normativo, la locura institucional: busqué construir un hablante femenino habitado por todas esas voces, para dar cuenta de la imposibilidad de comunicarse en esta era de las comunicaciones; hablamos de los años noventa. Ahora bien, Cierta femenina oscuridad se publicó en 1996, después de El cofre y antes de Lóbulo. Quería con Lóbulo tomarme todo el tiempo necesario para construir una novela. Me dije: yo quiero hacer una novela auténtica, porque sabía que Cierta femenina oscuridad era un texto bastante experimental: entre prosa poética y discurso dramático. Entonces armé todo, atando cabos para dar con las estructuras de cada capítulo. Aun así, en Lóbulo sigue existiendo una estructura dispersa que se fuga del engranaje. En uno de los tres finales su personaje, Sofía, muere taponado de papeles; en otro ella busca sacarse el mal de adentro y se hace cortes sobre los brazos para borrar el daño y establecer una primera cicatriz, y en el tercero hay intervenciones metaliterarias del autor.

KK: Parece un delirio que radica en la falta de comunicación por darse estas interferencias narrativas.

EP: Y está lo de mutar: la mutación que tiene que ver con la vida cotidiana. Para muchos, la experiencia de humanidad está cruzada por las máquinas; somos bichos tecnológicos. Te digo, yo sin mi computador soy nada; casi vivo en mi computador, todo el tiempo conectada a la red frente a una pantalla. Entonces, si nos quitan los computadores, nos vamos a volver locos un rato largo, porque vivimos en interferencia constante de las tecnologías y de las voces de los otros, también conectados a la "gran máquina". 
KK: La tecnología ya es una vida paralela, es un mundo coexistente con el palpable, físico.

EP: Mi conexión con la máquina -con el teléfono- nace cuando no había computadores, menos Internet. Me empecinaba imaginando los cambios que se nos venían encima. Eso podía verse, por ejemplo, en los relojes, calculadoras, aparatos pequeños y confusos con funciones que tenían doble utilidad, en que los objetos eran cada vez más plásticos y baratos. Con el desarrollo de los procesos productivos, vivíamos el vértigo de los objetos y la serialización.

KK: Antes era con los teléfonos fijos y ahora es con los celulares, todos los dispositivos móviles.

EP: Claro, no es otra cosa. Entonces, busqué indagar más en la comunicación y en 1996 nace Cierta femenina oscuridad. Mariano Aguirre, ensayista chileno, editor del diario La Época, me citó para hablar del libro, y dijo: “Este libro es una tragedia griega contemporánea. Y yo sé que tú nunca has leído tragedia griega, pero es lo que escribiste". En este libro trabajo lo religioso. El capítulo "La castidad" termina con esto: "En principio fue el verbo... Sus primeras vocales", y sigue el final del texto: "EVA / Evaluar / Evangelio / Evaporar / Evasión / Evidente / Evocar / Evohé / Evolución”. Todos estos cruces que le di a "Eva..."; fíjate que no existe un "Adan-gelio", sino un "Evan-gelio".

KK: Me hace recordar los poemas Evohé de Cristina Peri Rossi. Como observé en un artículo en la Revista de Estudios Hispánicos [Tomo 39, № 1 de 2005 -KK], predomina la ambigüedad de voces que se diluyen, se entrelazan y transitan entre los géneros masculino y femenino.

EP: El sujeto femenino se disuelve finalmente y es el texto. Este libro [Cierta femenina oscuridad] se transformó en obra de teatro en dos oportunidades. En una de ellas, Karina Bacelli, directora, desarrolló un montaje con una estética que rememoraba la tragedia griega. Fue impresionante asistir al estreno, donde cuatro chicas, todas menores de veinte años, presentaban su examen de grado dirigido por Sebastián Dham, para la carrera de Artes Escénicas de DUOC (Instituto de Educación Superior Chilena creado por la Pontificia Universidad Católica de Chile). Días después, nos juntamos a conversar, y las chicas decían que todas las mujeres deberían conocer el texto porque ahí estaba todo lo que las mujeres debían 
saber: víctimas, mártires, sumisas, furiosas, rabiosas, todas...

KK: Entonces, ¿es una obra dramática por excelencia? Porque yo sabía que escribiste un drama.

EP: Te refieres a Desórdenes mentales (2005), un texto escrito para teatro, pero eso vino después. Sin embargo, Cierta femenina oscuridad bordea lo teatral, no con una conciencia de, sino con una intuición para lo dramático. Producto de la experiencia: es que cada vez que me juntaba con alguna mujer, aparecía el tema de los hombres. ¿No habrá otro tema que tengamos las mujeres que no sea el amor, la familia, los hijos? ¿Teníamos que padecer así por amor todo el tiempo? ¿Hasta cuándo? El libro, también fue reseñado por Diamela Eltit en la contraportada. Ella me incentivó a llevarlo a Editorial Cuarto Propio y me contacté con Marisol Vera, que fue muy receptiva. Fue mi primer libro editado por una editorial consolidada y que acogía principalmente escrituras femeninas. Gracias a Diamela, la novela viajó lejos. Ella ha sido muy generosa y a lo largo de la vida me ha ido conectando con personas claves en momentos específicos.

KK: Con Cuarto Propio esto ya fue salir hacia aguas más anchas.

EP: Que me llevarían más allá de las fronteras de Chile. Editorial Cuarto Propio se encargó de que Lóbulo, Cierta femenina oscuridad y también Objetos del silencio estuvieran en universidades y librerías de Estados Unidos y Europa.

KK: Es interesante ver tu obra como una serie de transiciones, como una búsqueda...

EP: Durante más de seis años trabajé en la construcción de la novela Lóbulo, no había resuelto el libro cuando irrumpió Cierta femenina oscuridad, fue algo que estaba contenido y se derramó con fuerza. También tenía que ver con mis procesos personales. He tenido que trabajar duro y, por lo mismo, aprendí a ser detallista, corrijo muchísimo -cada página- apretando, sacando, desplazando y moviendo textos. Mi trabajo interviene en las estructuras del lenguaje, su sintaxis, elaboro distintos planos para un mismo sujeto, que es finalmente el texto, pongo y quito artículos, cambio preposiciones hasta que siento que las palabras brillan como pequeñas perlas, y estoy segura de que en una frase no hay nada más que hacer. En ese proceso, algunos textos se vuelven herméticos, otros poéticos, o más abstractos. Primero verifico que los capítulos funcionen, luego trabajo a nivel de frase y finalmente de palabras, como piezas mínimas 
que se van sumando en los engranajes. Cuando escribí Lóbulo, hice una estructura de base: pensé una parodia, lo melodramático. Pensé entonces en cruzar un teléfono -aparato, objeto útil que porta estas hablas desconocidas, las de Sofía, la protagonista- con un hombre que la llama persistentemente. También pensé en una serpiente; y ahí se puso un poco más complicado: una serpiente con sus representaciones simbólicas del pecado católico occidental y sabiduría, desde una concepción oriental. Mi personaje se transforma en serpiente, eliminando la piel que la cubre, luego sus órganos se comprimen y la morfología se reorganiza para adoptar un cuerpo "otro" de reptil.

\section{HEMBROS}

KK: Me interesaría que abordaras el elemento visual en tu obra. ¿Cómo se sitúa en tu creación?

EP: Precisamente, después vino la novela-instalación Hembros que incorpora, además de otras disciplinas de las artes, el video. El proyecto nació de algunas conversaciones con John Streeter, músico de teatro y compositor de obras; él me dijo: "Tú tienes unos textos que en la dramaturgia sonarían increíbles". Después, junto a Cecilia Godoy -actriz- hicimos este trabajo en equipo. Hembros se creó bajo el concepto de una ópera: música, texto, coreografías, vestuario, escenografía. La instalación se estrenó en 2004 en el Galpón Víctor Jara. Inclusive, hasta ahora sigo trabajando esta "novela en proceso", imagino que será un buen libro y que terminaré de escribirlo en algún momento. El texto dice: "Hombre + hembra = hambre". Hubo un cambio de paradigma y, en un momento, hombres y mujeres dejamos de entendernos, la comunicación se hizo cada vez más compleja y difícil, por lo que se volvieron más interesantes y abiertas las tensiones entre los géneros. Curiosamente, yo siento que mi mundo emocional, mental y afectivo está más vinculado a lo diverso, lo que no está en el binomio de lo masculino/femenino, me siento más cerca de géneros otros, o singularidades que han ido instalándose en lo público. Es ahí donde me siento parte de algo: valorada, acogida, respetada, y he podido establecer mis mejores vínculos. 
KK: ¿Por qué crees que ocurre esto?

EP: Cuando tenía ocho años se separaron mis padres. Mi hermana menor y yo estábamos en un nuevo escenario: nos quedaríamos a vivir con mi padre y mi abuela. Eso fue clave: no vivir con la madre como referente marcó otro lugar. Mi papá era contradictoriamente muy tradicional, pero no religioso; investigador y tecnócrata, diría yo, a la vez un trasgresor y además masón. Siempre decía: "Espero que mis hijas jamás dependan de un hombre". Vivíamos en un barrio de clase media y tenía muchos amigos hombres, me sentía como un chico más y muy a gusto con ellos. Recuerdo que corríamos persiguiendo a las niñas con unas cerbatanas de cañerías de cobre y les tirábamos plumillas de papel; me gustaba subirme a los árboles y era muy energética. Coincidió que mis mejores amigos de mi pubertad y adolescencia eran más ambiguos. Cuando ya fui adulta, al establecer mis relaciones en los ambientes literarios, inicié vínculos y complicidades con otros que, como yo, habitaban los mundos minoritarios. Es mi lugar, me siento a gusto en estos espacios.

KK: Es un lugar que no es comprendido desde el mundo de afuera, el rígido mundo tradicional.

EP: Hay un tema con el poder también, es incómodo; detesto algunas actitudes, donde se conjuga poder y ambición. Decidí no situarme en los espacios normados y construidos por escritores hombres, que podían ser muy arrogantes; soy una escritora piola [en Chile significa ser cool -KK]. No me interesa estar peleando los espacios.

KK: ¿Puedes explicar la evolución de Hembros?

EP: Hembros es una novela en proceso. Acordamos con John trabajar este texto desde distintas disciplinas. Invitamos a Cecilia Godoy, actriz y bailarina, que además de actuar, definió coreografías para el montaje; Marcelo Vega desarrolló los videos; la música original la compuso John; y yo, en los textos y la gráfica del montaje; todo cruzado con tecnologías de punta a cargo de Antonio Zurita. La dirección fue colectiva. Hembros duraba aproximadamente una hora. Al inicio, la actriz está de espaldas contra el suelo bajo un plástico enorme y arrugado que cubre todo el escenario, desde ahí escenifica su coreografía y nace "hembros", como un ser que transita y emerge del espacio líquido hacia el oxígeno y la tierra; al levantarse en dos pies, formula sus preguntas existenciales que van cruzando 
estos discursos, a veces hegemónicos, otras incisivos, irónicos o desafiantes. Se establece la relación entre creatura y creador, cruces de ideologías, ideas y pulsiones, atravesados por las tecnologías actuales.

KK: Está el marco filosófico de la postmodernidad: devenires y tránsitos, identidades fragmentadas.

EP: Me interesaba trabajar los desplazamientos de la escritura, ampliar sus posibilidades de representación hacia otros soportes. En Hembros, la actriz desarrolla su espectáculo en un espacio angosto y largo (6 por 20 metros), el público se ubicaba a ambos costados lo que fue un tremendo desafío de actuación. Para la saturación de información, se usaron tres monitores, dos a los costados del escenario que se proyectaban contra pantallas de unos $3 \times 5$ metros enfrentadas, y otro desde el cielo raso contra el suelo, allí se proyectaban los videos, fotografías e imágenes. Completando la escena, en un extremo se ubicaba John Streeter que intervenía con música en vivo y en otra esquina estaba yo leyendo algunos textos en vivo, más hacia al final. Pusimos a funcionar una máquina compleja para representar estas cadenas de acontecimientos simultáneos. Lo humano mutante circula y transita por el centro de la ciudad, Santiago está plagado de letreros, intervenido por la sobrecarga de tecnologías para el consumo. Manifiestan sus odios al padre, a todos los padres y sus instituciones, mientras sobre el suelo se proyecta un poema, "Sobre tus rosas yo escribiría estas primeras palabras".

KK: La disolución de la identidad o el tránsito hacia la desidentidad...

EP: ...espacios en que se originan las nuevas tribus, el inicio de otras formas de vínculos, relaciones, afinidades, políticas, intereses. Cuando hicimos esta obra, no existían redes sociales y no se producían estos flujos e intercambios entre los humanos desde puntos tan distantes y distintos del planeta.

\section{DESDE 2005: DESÓRDENES MENTALES Y OBJETOS DEL SILENCIO}

EP: Luego de eso, trabajamos Desórdenes mentales con el mismo equipo, junto a John Streeter y Cecilia Godoy. Fue una obra de teatro a la que luego se integró Alejandro Trejo como director. Entonces, 
escribí un texto sobre cuatro mujeres encerradas en un sótano. En ese momento se había instalado la discusión en Chile sobre los espacios de reclusión para la psicopatía y el delito, un tema de la psiquiatría forense no resuelto. Cuál era el espacio de reclusión social para los psicópatas, conscientes, que bordeaban la crueldad o el crimen: ¿el psiquiátrico o la cárcel? Me interesó trabajar esa ambigüedad. Uno de los personajes es una asesina que mata a su marido por celos. Otra, es una presa política de la dictadura que está siempre con una camisa de fuerza. En este trabajo investigué algunos casos del Informe Valech (registro de torturados políticos en la dictadura militar). Viví y me desarrollé en dictadura, tenía una deuda con eso. Tenía que tener una postura. Fue una obra potente, mi estreno como dramaturga y, al mismo tiempo, mi distancia con el teatro. Terminé agotada y dije: ya no quiero estar aquí. Cuando trabajas con un equipo, con actores, te das cuenta que a veces pueden oponerse o imponerse al texto.

Cambiando de tema, este es mi último libro: Objetos del silencio, publicado en 2007. Esta historia atraviesa la sexualidad de los niños. Lo que me interesaba era abrir el espacio de la sexualidad infantil; pienso que todos en la vida hemos tenido secretos y muchos se relacionan justamente con ese despertar; fue lo que descubrí después de varias entrevistas. Todas las historias que aparecen en el libro están basadas en experiencias reales y me costó bastante conseguirlas, porque nadie quiere compartir sus secretos, menos con extraños. Uno de los casos que más me sorprendió fue el de una niña que se inició con un perro, y obviamente para la entrevistada no fue fácil hablar de eso. Hay niños que se iniciaron con sus padres o madres, hay relaciones entre familiares, primos, amigos, hermanos; la iniciación sexual de los niños es un tema muy poco explorado, al menos en Chile. Me interesó políticamente trabajar con la historia de dos hermanos como eje de la novela. Hermanos que se inician sexualmente y siguen sus prácticas hasta de jóvenes adultos. Hay una relación simbiótica y de mayor fragilidad entre estos hermanos y de amor, por supuesto. El único personaje inventado de esta novela es la madre. En el Epílogo, se nos revela que es la madre la que escribió la novela, cuando dice: "Cierro el manuscrito". La madre sitúa el lugar de la rancia aristocracia chilena, encarna simbólicamente ese poder. Una madre que incita a sus hijos al 
incesto, pues ambos son hombres y no tendrán descendencia, y ella no tendrá que compartir su territorio, una metáfora de la mezquina clase alta chilena que concentra poder económico, político, social, mediático para reproducirse.

KK: Claro, ¿no es cierto que en Latinoamérica esta clase está en una línea de herencia directa desde los tiempos de la Independencia o aun antes?

EP: Absolutamente, y por eso, si este libro lo leyeran algunas personas que pertenecen a ese lugar (donde además sabemos que se produce incesto, abuso sexual y otras situaciones, como algo que atraviesa trasversalmente las clases sociales), creo que se sentirían al menos irritados. Pero mi libro se conoce poco. Al final, en un apéndice trabajé desde lo literario, con cruces de textos teóricos (Michel Foucault), del código penal, de apuntes o papers de la psicología local, interviniéndolos, también un texto del Marqués de Sade de La filosofía del tocador, por algo que aparece textual: "Los hombres en las costas de Chile se acostaban con sus hijas". En Chile el incesto, la violencia sexual y el abuso de menores tienen estadísticas elevadas, pero de eso no se habla, es un tema silenciado. Me interesaba develar las historias de niños y niñas como sujetos erotizados, como individuos en formación que tienen una relación inevitable con un cuerpo que crece, que existe, aun si algunos quieran negarlo.

Este libro no ha recibido atención de la crítica en Chile. Pienso que mis libros buscan entrar en esas capas más oscuras, prohibidas de lo humano. Imagino que son temas que incomodarán a algunos pero que tendrán también sus lectores.

\section{DE HEMBROS A ASEDIOS}

EP: Hemos hablado de todo lo que he publicado. Ahora, te voy a contar de esta obra en proceso, que es la continuación de mi novela Hembros, un libro que me interesa publicar algún día. Mi idea es que este libro incorpore elementos de la gráfica, las imágenes, lo visual. Me interesa trabajar con este material fotográfico; por ejemplo, fotos familiares de mis bisabuelos; al menos hasta este momento. Sabes que todo puede cambiar en estas $\operatorname{cosas}^{2}$. Siempre estoy fugándome de los géneros literarios, me parece más interesante y acorde con mi producción como escritora. 
KK: Esta es la ventaja que tienes de ser diseñadora y, combinándolo con el oficio de escritora, estás cruzando los géneros artísticos completamente, además de que cruzaste ciertos espacios geográficos. EP: El año 2000 me fui a Vallenar. Queda en el centro-norte de Chile, cerca de Copiapó. Bueno, llegué en calidad de señora del único psiquiatra de un pueblo de menos de 45.000 habitantes. Nuestra relación se fracturó de manera irremediable, en poco más de un año estaba de vuelta. En Vallenar no era nadie, ni escritora, ni diseñadora gráfica, no tenía amigos y entendí que en Santiago tenía un lugar. Mi proyecto literario de los diez últimos años se gestó allí. Busqué trabajar situaciones bien límites. Cito de Hembros: "Cierras el archivo, en un segundo la información desparece, vuelves a abrirlo: doble clic, lees y relees. Han pasado más de siete años". Y pasaron más de siete años en que estuve conectada casi todo el tiempo a un computador. Este texto sitúa a una mujer sentada frente a un computador y su deconfiguración frente a una pantalla; cualquier mujer conectada a cualquier computador en cualquier lugar del mundo, pero en el texto es ella misma la que escribe.

KK: Hay esa conexión sensorial. Como autora, realmente no quedas desconectada por lo virtual en lo textual, es decir hay una conexión física constante entre el lector y el autor por medio del texto.

EP: Por eso, pienso trabajar con tipografías, cuerpos y tamaños. Me gustaría recuperar algo de la biografía, lo femenino, en las percepciones de otras mujeres encerradas. Me interesa trabajar con textos como bloques sólidos, y otros cuerpos de textos que fluyen y flotan en un mismo espacio que es este espacio -el soporte del libro- establecer tensiones textuales desde una reflexión de lo actual. Quiero trabajar algo más experimental, darme esa libertad, de trabajar la biografía. Finalmente, siempre estás hablando desde ti. ¿Por qué? Porque ¿quién es tan distinto? Nadie. Somos todos más de lo mismo, nos pasan las mismas cosas; somos igualmente frágiles y necesitados; y a la vez, manifestamos una particularidad en todos estos "yoes" que se desplazan y mezclan con otros.

KK: Las particularidades son culturales, ¿no crees? Lo particular es lo que nos impone la cultura, que es la formación, pero tú hablas de cierta esencia existencial, de un cierto estado preverbal.

EP: A todos nos duele algo la vida en algún momento, todos tenemos deseos, pulsiones. ¿A quién no le va a doler que otro le haga 
daño, lo agreda o violente? Sin embargo, hay personas que están mejor equipadas o adiestradas, que han vivido guerras, hambre o experiencias traumáticas, por ejemplo, la muerte de seres queridos o cercanos. En el otro extremo, conocemos el placer, la alegría.

\section{DE POLÍTICA, CULTURA Y NUEVAS IDENTIDADES}

EP: El "yo" es un bicho acosado, afectado por otros permanentemente. ¿Cómo abstraerse de las guerras que aparecen en televisión, cómo, si vemos que algunos se exceden en el uso de la energía y los recursos naturales en beneficio de muy pocos, perjudicando o depredando a las mayorías? Existen intereses económicos, políticos, mediáticos. No se puede hacer como si nada sucediera. Todos los días estamos recibiendo información, todos los días estamos viendo estas cosas de un mundo abierto y mediatizado, donde priman los conflictos de intereses y de todo tipo. ¿Qué nos pasa con eso? ¿Qué les pasa a personas que viven una súper precariedad sometidas a promesas de lujo y placer en las pantallas? ¿Dónde irán a parar todos esos deseos? ¿A qué resumideros?

KK: Muchas personas viven en un mundo simulado, en una simulación de una ficción mediática, controlada por establecimientos de poder.Siempre a merced de la élite está el puebloy, aparentemente, todo va bien.

EP: Aparentemente todo está bien controlado, pero yo tengo esperanzas en esta época, a pesar de que pareciera que todo se viene abajo, de que algo suceda, un cambio radical.

KK: ¿En esta época de la "post transición democrática" y del neoliberalismo rampante?

EP: Tengo esperanzas porque considero que las herramientas de escritura, expresión y comunicación que tenemos a la mano son poderosas y pueden expandirse mejor, la comunicación es más inmediata. Vivimos una verdadera revolución cibernética. Hoy cada vez más personas nos enteramos de todo. Entonces, ¿cómo no vamos a tener esperanzas de que algo positivo suceda, algo que modifique las cosas? Si estamos más comunicados y conscientes, sabremos qué hacer.

KK: Dejando el sujeto individual y pasando al entorno colectivo... y observando un poco la estética de un estilo tan latinoamericano 
como el "neobarroco" -me refiero aquí a la escritura de un Severo Sarduy o Néstor Perlongher- ¿cómo percibes tú las conexiones entre la estética y la política?

EP: Somos sujetos que trabajamos el lenguaje, somos políticos, generamos ideas a través de las palabras, el lenguaje es lo más humano que existe. Por mi parte, busco disolver esos "yoes" autoritarios y tan determinantes de nuestras conductas... Podemos detonar minirevoluciones en los espacios que habitamos, con las herramientas que tenemos; hoy es posible ser más generosos, desde la periferia es posible hacer y construir sistemas propios de reciprocidad. Es increíble lo que podemos ser y hacer hoy, que los accesos a las tecnologías amplían nuestras posibilidades de ver, conocer, sentir desde las múltiples identidades, géneros, razas, credos, y particularidades humanas.

KK: ¿Serán especies nuevas de tribalismos o de conexiones risomáticas?

EP: Mutamos hacia nuevas formas de contacto; esto tiene que ver con las identidades mutantes. No es a lo que estábamos acostumbrados hace décadas; hoy los territorios se amplían considerablemente. Habitábamos antes el espacio local, luego fue el desplazamiento por el mundo, ahora nos desplazamos en el tiempo, y no en una sola Identidad determinada, fija e impuesta. ¿Cómo puedes acotar mejor los datos si la Internet domina todos los espacios? Te enteras, por ejemplo, que en China las mujeres están produciendo textos increíbles, o en Polonia, o en distintos lugares. Antes no teníamos esos accesos. Por eso, en la representación de Hembros todo era simultáneo. Los espectadores no sabían si concentrarse en mirar las pantallas, las imágenes, los textos, escuchar a la actriz o al músico, o rehuir de los focos que los apuntaban. Como sujetos históricos estamos viviendo una revolución tremenda. Luego del fracaso de los humanismos, aparecieron los posthumanismos, las tribus (de vuelta) o los parques humanos, la antipsiquiatría; además de la manipulación, la biogenética en humanos, animales, semillas. Pienso lo femenino como una percepción activa de lo simultáneo y de estos nuevos lugares minoritarios que se van incorporando sobre la superficie de este gran tejido en que han venido apareciendo diversas crisis de roles de géneros, de castas y privilegios, y sobre todo, percepciones de abusos, desigualdades, odios... 
KK: En fin, estás en un lugar límite de la reflexión cultural, de la vanguardia artística en Chile.

Llegué aquí con ciertas referencias a escritores ya más o menos institucionalizados, pero con la intención de descubrir voces nuevas. Tuve la suerte de conocerte a ti y a Juan Pablo Sutherland quien ha recibido atención crítica, pero también en el polémico mundo de la política.

EP: Juan Pablo es activista, político, sus textos circulan por la teoría y la narrativa, sitúan los lugares de las minorías. Pero así como él, que es un cómplice directo, hay dos poetas chilenas: Malú Urriola y Eugenia Brito, tremendas poetas; Eugenia Brito además es una gran teórica, ambas han sido amigas y referentes estos años. Aparte de eso, ahora, estamos dando un taller de novela con un poeta joven, Diego Ramírez. Políticamente, él me interesa así como su proyecto de escritura, sus talleres Moda\&Pueblo donde se producen textos jóvenes, rebeldes.

KK: La reunión con Felipe Rivas y los estudiantes de la Coordinadora Universitaria por la Disidencia Sexual (CUDS) también me abrió un nuevo mundo de referencias literarias en Chile.

EP: Felipe, al igual que Jorge Díaz (CUDS), transita, sitúa y desplaza sus rebeldías en los espacios de la academia, lo que genera una tensión interesante. Lo hacen por medio de su revista Torcida. Hablando de espacios, existió una apuesta dramatúrgica y tecnológica también en el montaje de Hembros que situó un lugar nuevo en el panorama cultural en Chile. Nadie había instalado una novela en escena antes. KK: Sí, pues. Son espacios bastante transgresivos. Tanto más me alegro de haberme podido contactar contigo y de conocer más tu obra por medio de esta conversación reveladora. Más que una entrevista, fue toda una experiencia literaria y cultural para mí. Muchas gracias.

EP: Para mí ha sido un gran placer. Después de todo, ¿cuándo es posible hablar de la propia obra con estos niveles de profundidad? Además de las coincidencias y afinidades, trabajas temas que me apasionan. Por lo mismo, lo hice con mucho gusto.

\section{Notas}


1. Desde que se realizó la entrevista en 2009, Prado ha cambiado el título de esta novela en proceso (todavía sin publicar). El texto ahora se titula Asedios.

2. A mediados de 2011, Eugenia Prado y Dauno Tótoro, narrador chileno y amigo, decidieron crear un proyecto editorial: Ceibo Ediciones. Para ello tenían que publicar varios libros en un tiempo reducido. Según información obtenida de la correspondencia de KK con EP (posterior a la entrevista), esta urgencia coincidió con que Prado había estado trabajando con la novela Hembros (retitulada a Asedios), y su socio la desafió a terminarla. Otro impulso que influyó en considerar una pronta publicación fue la lectura que Diamela Eltit hizo del manuscrito, cuando Prado estaba en su taller de literatura creativa. Luego de revisar lo que había estado trabajando, entendió que una parte del texto estaba incrustado en la costilla de Asedios (anteriormente Hembros), y que aparecía como un capítulo aparte, incluso en el uso de las imágenes. Por lo mismo, la autora decidió separar los textos y así, a partir de Asedios, nació la novela Dices miedo, publicada en 2011.

\section{Referencias}

Brown, J. Andrew. Cyborgs in Latin America. New York: Palgrave Macmillan, 2010. . "Identidad poshumana en Lóbulo de Eugenia Prado." Revista Iberoamericana. LXXIII, 221 (2007), 801-812.

Deleuze, Gilles y Félix Guattari. Anti-Oedipus: Capitalism and Schizophrenia. Minneapolis: U of Minnesota P, 1983.

Haraway, Donna J. Simians, Cyborgs, and Women: The Reinvention of Nature. New York: Routledge, 1991.

Hayles, N. Katherine. How We Became Posthuman: Virtual Bodies in Cybernetics, Literature, and Informatics. Chicago, London: U of Chicago P, 1999.

Hopenhayn, Martín. "No Way Out: Comentario a Lóbulo de Eugenia Prado." Sep. 25, 2010. www.critica.cl. 24 de febrero, 2005,1-3.

Kulawik, Krzysztof. “Lenguaje en celo: análisis de la transgresión sexual en los poemas de Evohé de Cristina Peri Rossi". Revista de Estudios Hispánicos. XXXIX 1 (2005). 129-51.

Loebell, Ricardo. "Repeso de un ensayo: a propósito de la narrativa de Eugenia Prado". Literatura y lingüística. Versión electrónica. Santiago de Chile. No 12 (2000), 167-181. http://www.scielo.cl/scielo.php. 25 de septiembre, 2010, 1-11.

Poblete, Nicolás. "Engendrando el texto posthumano en Lóbulo de Eugenia Prado". Ensayo final -Spanish 599. Professor J. Andrew Brown. Washington University in St. Louis. S.f.http://www.critica.cl/html/poblete_01.html. 30 de septiembre, 2010.

Peri Rossi, Cristina. Evohé: poemas eróticos. (1971). Ed. bilingüe. Trad. Diana Decker. Washington, DC: Azul Editions, 1994.

Prado Bassi, Eugenia. Cierta femenina oscuridad. Santiago de Chile: Cuarto Propio, 1996.

--------. Desórdenes mentales. Dramaturgia, dirección de Alejandro Trejo. Estrenada en La Casona Nemesio Antúnez en Santiago de Chile, 2005.

------. El cofre. Santiago de Chile: Caja Negra, 1987.

-------. El cofre. 2ª ed. Santiago de Chile: Surada Gestión Editorial, 2000. -. ${ }^{a}$ Hembros: asedios a lo post humano. Beca Fondart Artes Integradas. Novela: instalación. Estrenada en el Galpón Víctor Jara en Santiago de Chile, 2004.

------. ${ }^{\mathrm{b}}$ Hembros. Novela (en proceso). Retitulada como Asedios en 2010.

------- Lóbulo. Santiago de Chile: Cuarto Propio, 1998.

-------. Objetos del silencio. Santiago de Chile: Editorial Cuarto Propio, 2007. 
-------. Dices miedo. Santiago de Chile: Ceibo Ediciones, 2011. http://eugeniaprado.blogspot.com/

Streeter, John, Eugenia Prado y Cristóbal Rojas. Hembros. Música original de la novela instalación. CD con música, videos, imágenes y textos. Beca Fondo de la Música, Chile, 2005.

Sutherland, Juan Pablo. "El cofre, la extraña tonalidad del lenguaje tránsfugo de Eugenia Prado". Prólogo a El cofre de Eugenia Prado. 2ª ed. Santiago de Chile: Surada Gestión Ed, 2000, 7-16. 